\title{
THE SAFE ROAD TRANSPORT SYSTEM APPROACH
}

Hans-Joachim Vollpracht, Ministerialdirigent a.D. Dipl.Ing., Honorary member of the World Road Association (PIARC)

\section{Abstract}

More than 1,24 million people die each year on the worlds roads and between 20 to 50 million suffer from nonfatal injuries. The UN Road Safety Collaboration Meetings under the leadership of WHO developed the Programme for the Decade of Actions for road safety taking nations into the responsibility of improving their accident figures by the five pillars of a national Road Safety Policy, safer Roads, safer Vehicles, safer Road Users and Post Crash Care. It is this Safe System Approach that takes into consideration the land use, infrastructure and transport planning, road user's abilities and limitations and the close cooperation of all governmental and none governmental stakeholders involved.

Following the European Transport Safety Council's (ETSC) 8th Road Safety Performance Index Report on Ranking EU Progress on Road Safety; June 2014 Romania has made progress during the last 10 year but had still the highest fatality rate of 93 fatalities per 1 million inhabitants in Europe. [1]

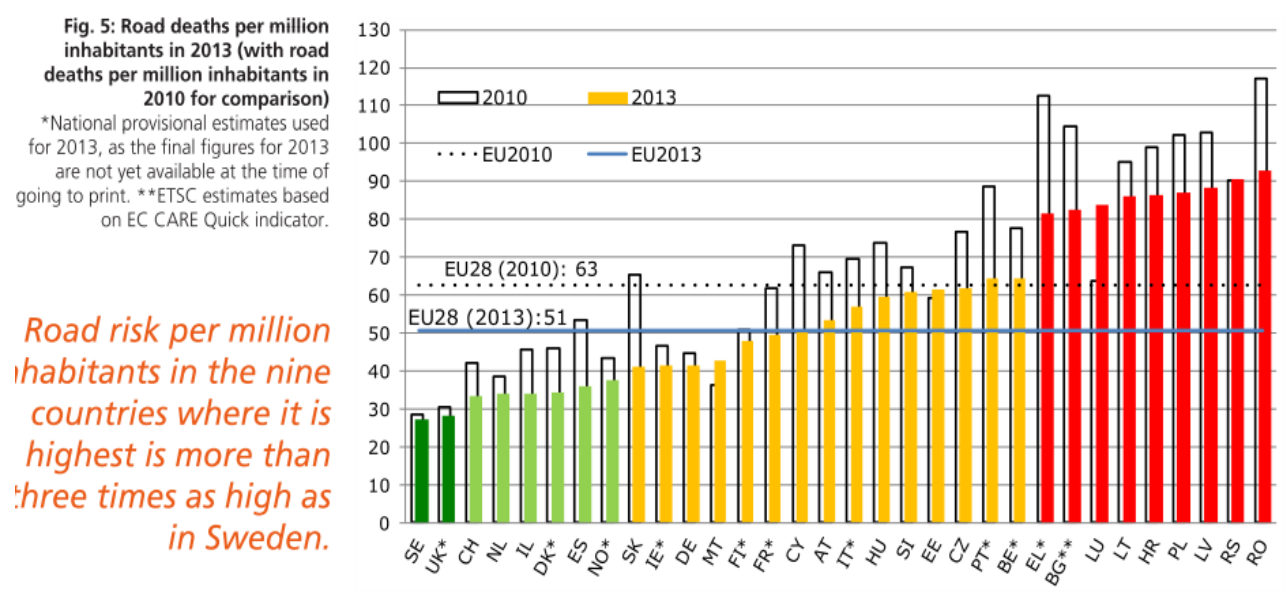

Figure 1. European Transport Safety Council's (ETSC) 8th Road Safety Performance Index Report on Ranking EU Progress on Road Safety; June 2014

The contribution will present the main activities of the fife pillars with a focus on PIARC's Road Infrastructure Management tools to improve safety and function of the road infrastructure based on the experiences with the land use problems in Asian, African and European countries. 
A GPS based accident data system will help researchers and practitioners to improve their countries road safety.

The report will show the important steps for safer roads which had been developed in Romania and how actions of short and long term measures on all five pillars have reduced the number of traffic victims remarkable in Eastern Germany after reunification and in addition how the hierarchy of motorways, $2+1$ express roads, the rural roads and traffic calming in built up areas, have improved the economic development of cities and villages in a safe way.

Keywords: UN Global Plan for Road Safety, GPS based accident data system, PIARC tools for Road Infrastructure Safety Management, Legal regulations on safer roads, linear settlements, the positive effects of the $2+1$ cross section within the road Hierarchy

\section{INTRODUCTION}

The reduction of travel times for people and goods on their roads is one of the most crucial objectives for enhancing and stabilising the economies. In emerging countries this is regularly done first just by resurfacing the old roads, which had been designed for low speeds, and by the removal of all road elements, which could reduce the speed of motor vehicles.

More than 1,24 million people die each year on the worlds roads and between 20 to 50 million suffer from nonfatal injuries.

In order of the UN-Assembly the UN Road Safety Collaboration Meetings under the leadership of WHO developed the Programme for the Decade of Actions for road safety taking nations into the responsibility of improving their accident figures by the five pillars of a national Road Safety Policy, safer Roads, safer Vehicles, safer Road Users and Post Crash Care.

It is this Safe System Approach that takes into consideration the land use, infrastructure and transport planning, road user's abilities and limitations and the close cooperation of all governmental and none governmental stakeholders involved.

The contribution will present the key-facts about road traffic victims world wide and the main activities of the fife pillars with a focus on PIARC's Road Infrastructure Management tools to improve safety and function of the road infrastructure.

It will be based on the experiences with the land use problems in Asian, African and European countries such as Romania, where the Road Administration and Traffic Police had recognized the road safety problems especially in their linear settlements in an excellent cooperation as it was found in two European Technical Assistant projects some years ago. These 
experiences had a great influence on the development of the above mentioned PIARC guidelines for safer roads as the contribution will demonstrate.

Unsafe rehabilitations of historical roads just by new asphalt layers like in many Balkan Countries where the reason for similar hazardous roads in Eastern Germany after the reunification with an extremely high fatality rates of 36 per 100.000 inhabitants in 1991, four times more than in Romania in 2013 [1]. The report will show how actions of short and long term measures on all five pillars have reduced the number of traffic victims remarkable to the European average of 2010 and in addition have improved the connections of cities and villages to the Trans European Road Network by the hierarchy of motorways, $2+1$ express roads, the rural roads and traffic calming in built up areas, a condition for their economic development. The stepwise development of such a system has been recommended for the Bacau Bypass in 2007 [12].

\section{KEY FACTS AND OBJECTIVES}

According to the WHO publication on road safety (www.decadeofaction.org) [2], road accidents are the leading cause of death of young people aged $15-29$ years and $46 \%$ of road traffic deaths are pedestrians, cyclists and motorcyclists.

$90 \%$ of road traffic deaths and injuries occur in low-income and middleincome countries which have only $48 \%$ of the world's registered vehicles.

The situation is worsening and among the 10 leading courses of death road accidents are expected to rise from place 9 in 2004 to range 5 in 2030.

\section{Worsening situation}

Top 10 leading causes of death

\begin{tabular}{|c|c|c|c|}
\hline \multicolumn{2}{|r|}{2004} & \multicolumn{2}{|r|}{2030} \\
\hline Rank & Disease or Injury & Rank & Disease or Injury \\
\hline 1 & Ischaemic heart disease & 1 & Ischaemic heart disease \\
\hline 2 & Cerebrovascular disease & 2 & Cerebrovascular disease \\
\hline 3 & Lower respiratory infections & 3 & Chronic obstructive \\
\hline 4 & Chronic obstructive & & pulmonary disease \\
\hline & & 4 & Lower respiratory infections \\
\hline 5 & Diarrhoeal diseases & 5 & Road traffic injuries \\
\hline 6 & HIV/AIDS & 6 & \\
\hline 7 & Tuberculosis & & cancer \\
\hline 8 & Trachea, bronchus, lung & 7 & Diabetes mellitus \\
\hline & cancer & 8 & Hypertensive heart disease \\
\hline 9 & Road traffic injuries & 9 & Stomach cancer \\
\hline 10 & $\begin{array}{l}\text { Prematurity \& low-birth } \\
\text { weight }\end{array}$ & \begin{tabular}{|l|}
10 \\
10
\end{tabular} & HIV/AIDS \\
\hline
\end{tabular}

Figure 2. The forecast of leading courses of death. Source: www/decadeofaction.org 
To stop this development the United National General Assembly declared in March 2010 the UN Road Safety Global Plan [3], as a guiding document that will facilitate coordinated and concerted actions within the Decade of Action towards Road Safety and the UN Secretary-General, Mr Ban Ki-moon, called on Member States, international agencies, civil society organizations, businesses and community leaders to ensure that the Decade leads to real improvements.

The overall goal of the Decade is to stabilize and then reduce the forecast level of road traffic fatalities around the world by 2020 and to follow the ,safe system approach" to develop a road transport system that is better able to accommodate human errors (chapter 4 of the Global Plan).

\section{THE GLOBAL PLAN}

The safe system approach of the UN Global Plan for the Decade of Action for Road Safety 2011-2020 is structured along the five pillars.

\begin{tabular}{|c|c|c|c|c|}
\multicolumn{5}{|c|}{ National activities } \\
\hline $\begin{array}{c}\text { Pillar 1 } \\
\text { Road safety } \\
\text { management }\end{array}$ & $\begin{array}{c}\text { Pillar 2 } \\
\text { Safer roads } \\
\text { and mobility }\end{array}$ & Sillar 3 & Pillar 4 & Pillar 5 \\
& & $\begin{array}{c}\text { Safer road } \\
\text { users }\end{array}$ & $\begin{array}{c}\text { Post-crash } \\
\text { response }\end{array}$ \\
\hline
\end{tabular}

Figure 3. The five pillars of the Global Plan of Action1

These pillars have the following objectives specified by activities

\section{Pillar 1: Safety Management-Activities}

- Strengthen institutional capacity

- Put in practice United Nations road safety conventions

- Establish lead agency

- Develop a national road safety strategy

- Set realistic and long-term targets

- Develop data systems

\section{Pillar 2: Safer Roads and Mobility}

- Improve safety-conscious planning, design, construction and operation of roads

- Assess regularly safety of roads

- Explore various forms of transport and safe infrastructure

${ }^{1}$ www.who.int/roadsafety/decade_of_action/plan/en/index.html 


\section{Pillar 3: Safer Vehicles}

- Harmonize global standards

- Implement new car assessment programs

- Equip all new cars with minimum safety features

- Promote use of crash avoidance technologies

- Encourage managers of fleets to purchase, operate and maintain safe vehicles

\section{Pillar 4: Safer Road Users}

- Adopt model road safety legislations

- Sustain or increase enforcement

- Promote public awareness of risk factors

- Call for activities to reduce work-related road traffic injuries

- Establish graduated driver licensing programs for novice drivers

\section{Pillar 5: Post crash Response}

- Develop pre-hospital care systems

- Put in place single nationwide emergency telephone number

- Provide early rehabilitation and support to injured patients and those bereaved by road traffic crashes

- Establish insurance schemes

- Investigate crashes and provide legal response

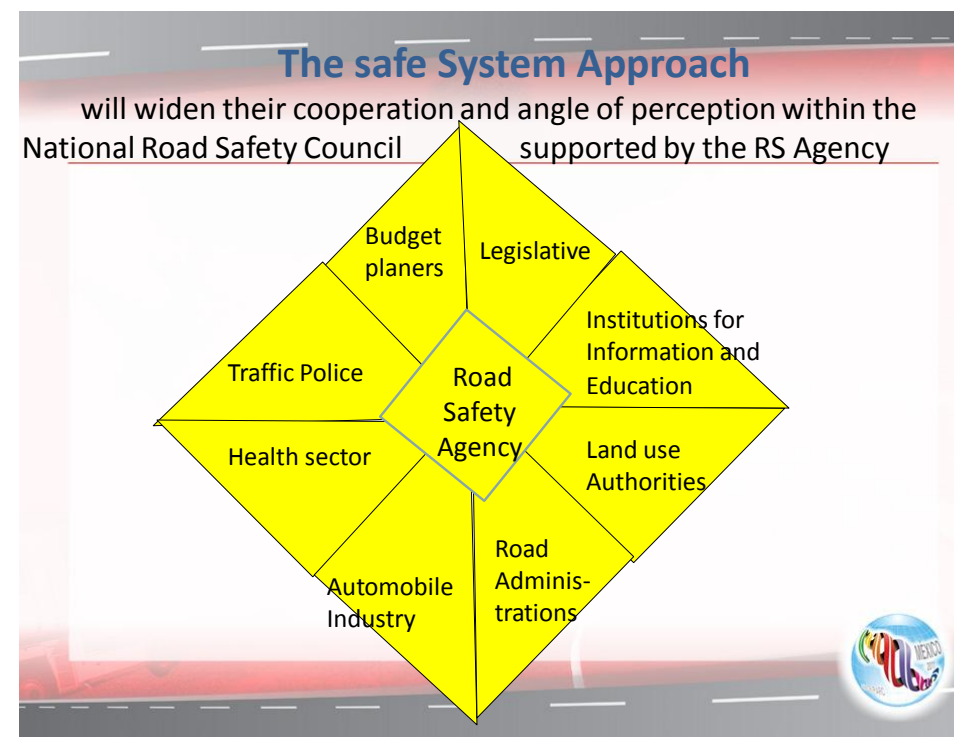

Figure 4. Presentation of the Author at the Building Road Safety Capacity

Congress in Warsaw 2013 
All these pillars are included in a network of governmental and none governmental responsibilities for Legislation and Organization, Information and education, land use and transport planning, urban development, Road Administration, Automobiles, Health and Enforcement. In most countries these stakeholders are not coordinated by a Road Safety Agency and are doing their own thing.

\section{DETAILS ABOUT PILLAR 2}

For a congress like ths pillar 2 has to be reported in details of the activities.

1. Promote road safety ownership among road authorities, - engineers and urban planers

- making them legally responsible for improving road safety on their networks through cost effective measures.

- establishing a road safety unit to improve the safety of the road network.

- promoting the safe system approach and the role of self explaining and forgiving road infrastructure.

2. Promote the needs of all road users by planning land use to respond to safe mobility... access needs, geographic and demographic conditions.

3. Promote safe operation, maintenance and improvement of existing road infrastructure by

- Black spot and network safety management

- Safety assessments of existing roads

- Speed sensitive design

- Work zone safety

4. Promote the development of safe new infrastructure

- By using Road Safety Impact Assessment and Road Safety Audits

5. Encourage capacity building and knowledge transfer

6. Encourage research and development in safer roads

\section{THE LEGAL RESPONSIBILITIES OF ROAD ADMINISTRATIONS}

From activity 1 in pillar 2 of the UN-Global Plan of Action we see at least the following objectives necessary to be regulated legally within countries road acts:

(1) Along rural roads and freeways the ownership of lands lying on both sides of public roads up to 75 meters for motorways, 50 meters for express 
roads, 25 meters for rural roads, shall not be used for any purpose other than agriculture, forest or gardening.

As in many other countries we found in Romania lots of billboards along interurban roads distracting drivers' concentration on traffic.

(2) For preventing heavy accidents from human errors forgiving road sides have to be guaranteed either by obstacle free zones of

$12 \mathrm{~m}$ along all roads with speed limits $>100 \mathrm{~km} / \mathrm{h}$

$10 \mathrm{~m}$ along roads with speed limits of $100 \mathrm{~km} / \mathrm{h}$

$8 \mathrm{~m}$ along roads with speed limits of $80 \mathrm{~km} / \mathrm{h}$ and

$6 \mathrm{~m}$ along roads with speed limits of $60 \mathrm{~km} / \mathrm{h}$

or, if these are not possible, by passive safety measures have to be installed such as crash barriers.

The Romanian road network had lots of road side obstacles such as the head walls of thousands of culvers. None of them is a black spot itself but many accidents are occurring at these head walls.
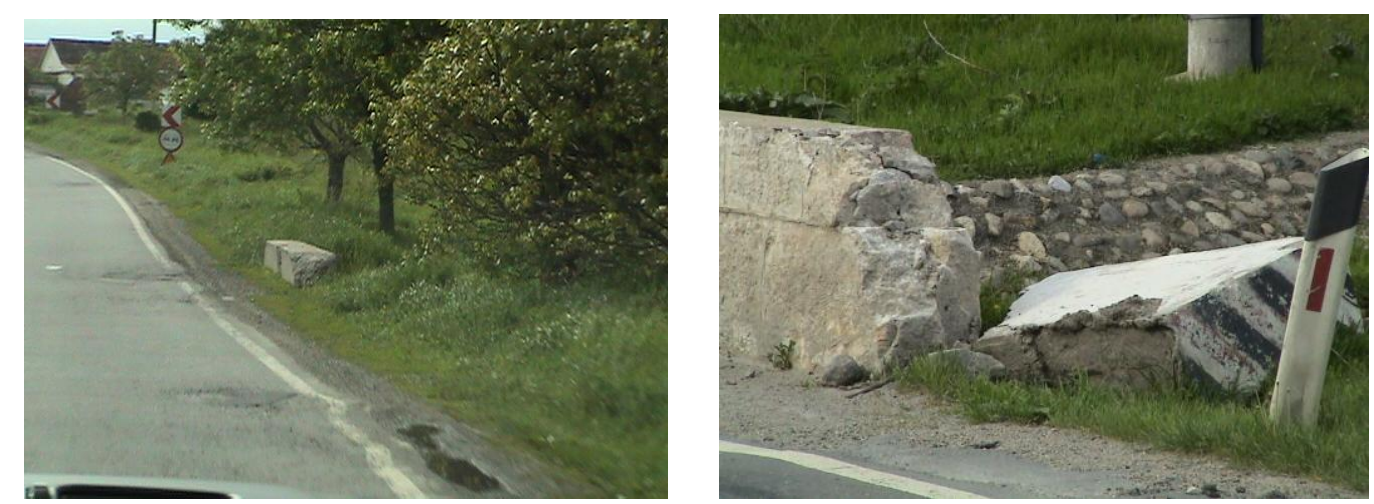

Figure 5. Headwalls of culverts are main road side obstacles in Romania (photos of the author)

This example of road safety deficiencies from the Catalogue for Remedial Measures in Romania [4] was a leading argument for the implementation of Road Safety Inspections world wide.

(3) Access control to private and public properties is a must for a safe highway system. A permission for access can only be granted if endangerment of road safety is excluded, such as for fire brigades, emergency services or the road maintenance.

The lack of access control along interurban roads is one of the most important road safety problems causing thousands of fatalities and severe injuries especially among vulnerable road users in nearly all emerging countries. 
We found it in Asia, especially India, Africa and European countries. Romania was the first country looking for solutions for these so called "linear settlements" in the European Technical Assistant project in 2004/2005 [4]. They may be the most decisive reason for the high mortality of other countries Croatia, Poland and Serbia as well. Unfortunately this is not clearly recognizable by the police reports and accident statistics.
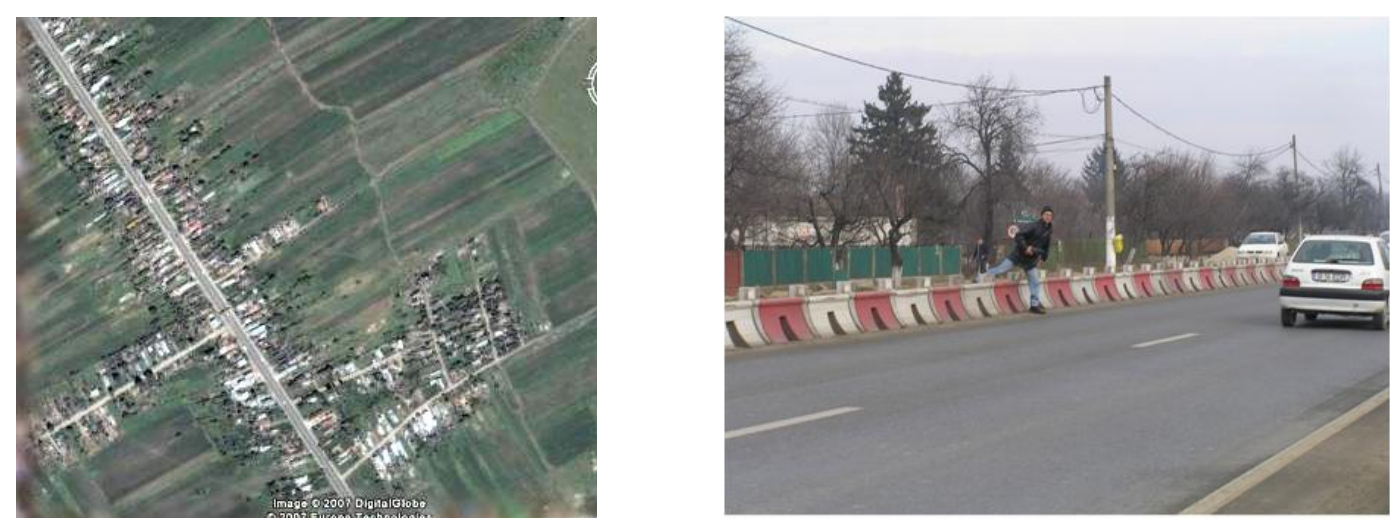

Figure 6. Linear settlements are well detectable by Google. (authors report in PIARC [5]).

Especially for the situation of the linear settlements along the Romanian National Road Nr 1, shown in Figure 6, general solutions have been proposed within the EU-Technical Assistant project for Implementation of Road Safety Measure in Romania, Europe Aid/121354/D/SV/Ro [13] as shown in Figure 7 below:

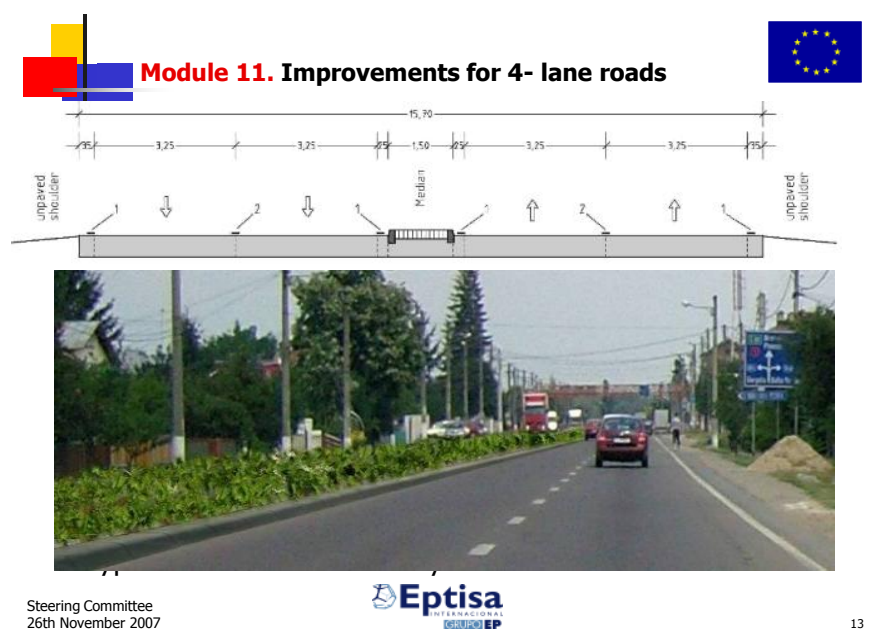

Figure 7. Proposal of a solution for a safer cross-section to the Steering Committee of the EU TA Project [13] 
(4) A fundamental approach for enhancing road safety is the launching of a Road Traffic Accidents Report System. This implies a legal report system from taking on accidents by police authorities to the transfer to all stakeholders involved in Road Safety. These are much more than usually mentioned.

They all need sufficient accident data for scientific research, programs and decisions to let the Road Safety Policy Circles turn around for the benefits of their populations.

It was created by the European Transport Safety Council (ETSC) in 2003 [6] and adapted to Road Safety.

\section{The Road Safety Policy Circles}

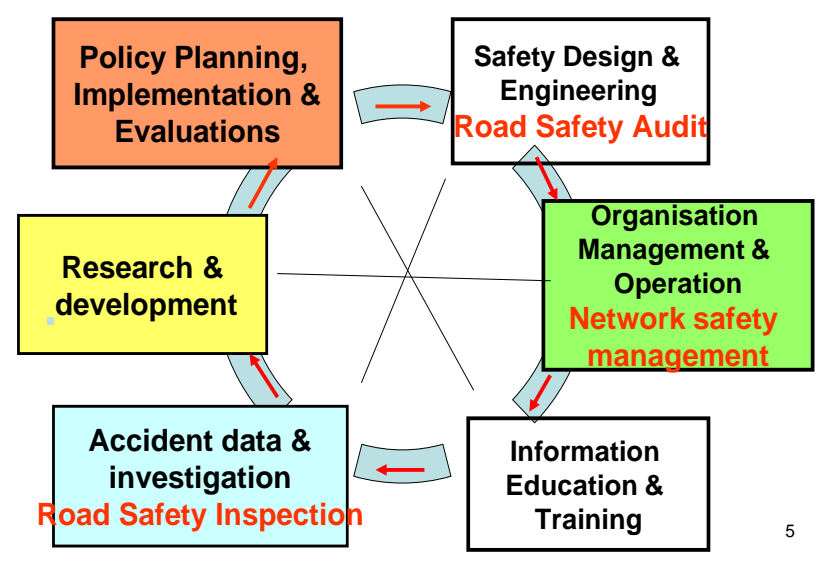

Figure 8. The Road Safety Policy circle

"Accident commissions" are working together to find out, at first along accident needle maps, later in digital accident maps, where black spots and hazardous road sections are located and discuss which kind of short and medium term measures might be most successfully, most of them related to road equipment and traffic calming measures in built up areas,.

Romania was head on to implement such commissions of representatives of Traffic police and Road Administrations. But in general Accident Data Bases should be improved by a modern GPS based Accident Data System as it was developed in an EU Twinning Project for enhancing Road Safety in Egypt [7].The personal accent data are collected separately so that the technical data about the road and vehicle situation can be reached by the Road Administrations, None Governmental organizations and Research centres, such as Universities, to develop the most effective countermeasures. 


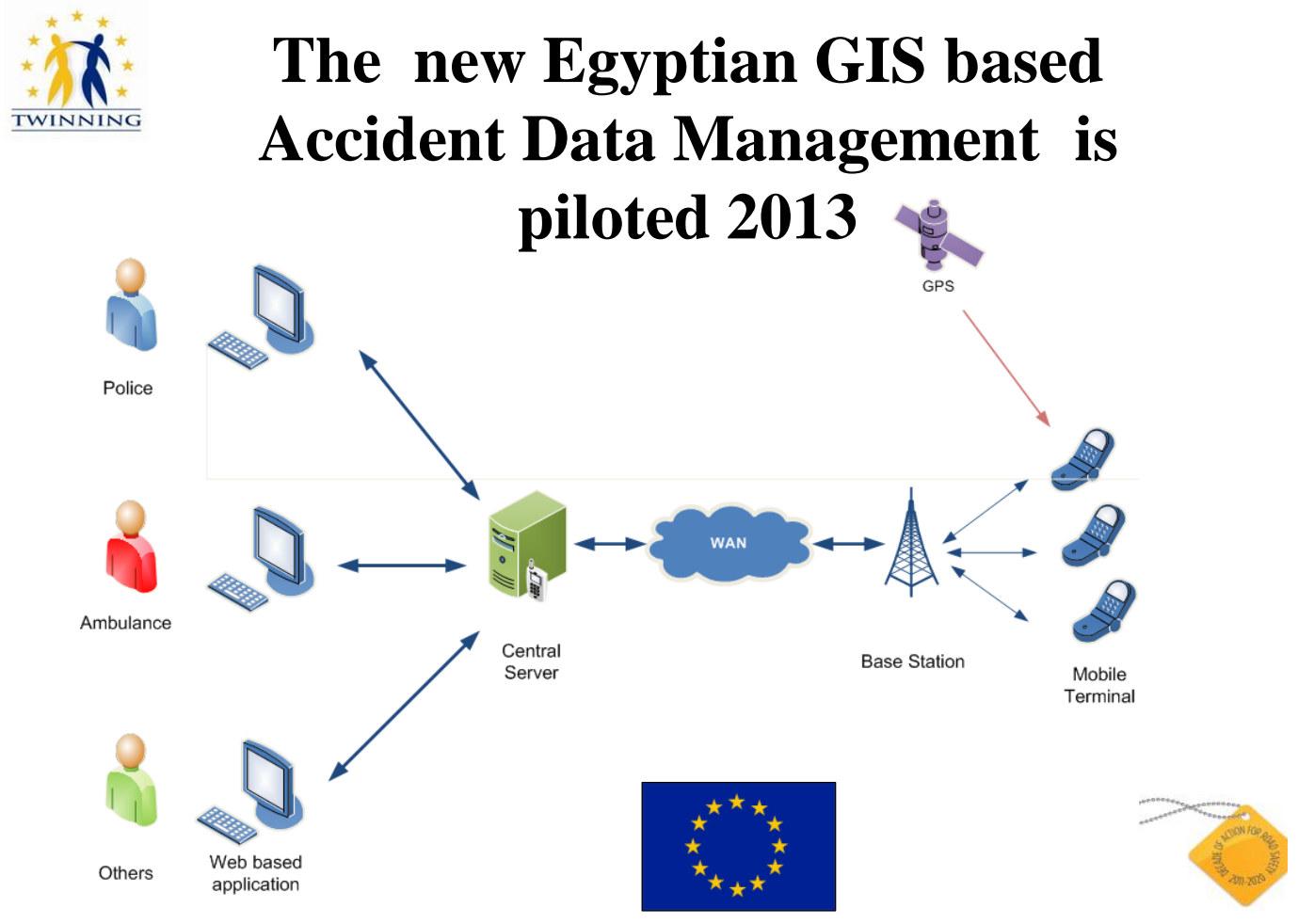

Figure 9. The modern GPS based Accident Data Management [7]

(5) The performance of Road Safety Audits and Inspections should be implemented by road acts. Romania had a leading position developing Road Safety Audit and Inspection guidelines and implementing these tools of Road Infrastructure Safety Management by legal regulations. They were used as the fundamentals for the Guidelines of the World Road Association (PIARC). We would like to know if today Road Safety Audits and Inspections are performed regularly.

(6) Service and Rest areas for the long distance traffic are part of the freeway network. In these rest areas there have to be parking facility for drivers of goods traffic, so that they can obey to the regulations for resting-periods. These rest areas are only dedicated for the needs of rapid traffic. The inhabitants of towns and villages nearby do not have direct access to the rest-areas, so that the aspect of road safety is taken into account. Road user services have been provided quite well along Romanian highways; the world has learned that along highways the next petrol station or parking place should be on the right side to avoid dangerous left - or U-turns across the opposed direction. This is an issue of planning and of legal regulations for giving permissions to the companies as well. 


\section{THE PIARC TOOLS FOR SAFER ROADS}

The World Road Association (PIARC) has, in 2014, 120 member governments from all continents. In the 2012 - 2015 cycle, PIARC technical Committees are structured along four strategic themes [8]:

1. Management and Performance for road administrations inclusive Financing and climate changes and sustainability

2. Access and Mobility inclusive road network operation, freight transport, winter service the accessibility of rural areas

3. Road Safety inclusive national policies, safer infrastructure and tunnel safety

4. Infrastructure Assets inclusive road pavements, bridges and earthworks (see www.piarc.org).

Technical Committees comprise specialists from both the public and the private sector who are tasked to share experience and identify best practises presented in technical reports and manuals. The outputs of the current cycle will be presented at the next World Road Congress in Seoul in November 2015. A new Strategic Plan will then define the directions of work for the following four years, hopefully with the renewed participation of Romanian experts. published:

During the last cycles important guidelines [9], on road safety have been

- Accident guidelines for engineers;

- Road Safety Audits and Rad Safety Inspections guidelines;

- A Catalogue of Design Safety Problems and potential Countermeasures(as mentioned above the guidelines for Romania had been the sources for these PIARC documents)

- Best Practices for Road Safety Campaigns;

- The PIARC Road Safety Manual, second edition, currently under development which will present a broad approach of road safety in relation to road infrastructures

- A comparison of national road safety politics;

- Work zone Safety, and last but not least

- Human Factors in road design and operation [10].

Road networks are integrated in the transport system with two main interfaces between the road users on one hand and the vehicles on the other.Whilst the physical factors are very well known by road and vehicle 
engineering since decades, the Human Factors between the road and the road users were thought to be an issue of road users training and enforcement only.

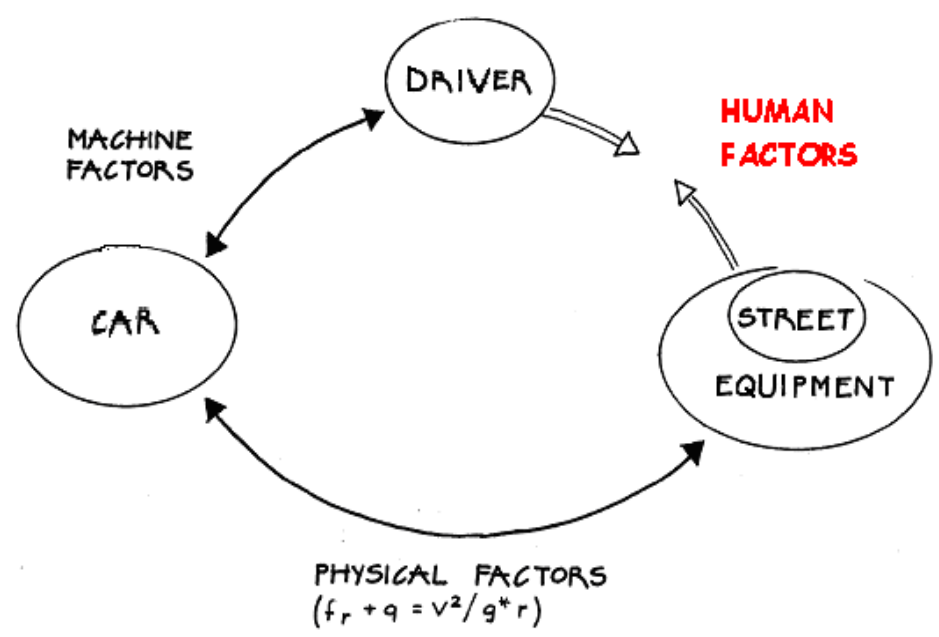

Figure 10. The main interfaces of the road transport system Source: PIARC Human Factor Guideline in safer design and operation [10].

"Promoting the safe system approach and the role of self explaining and forgiving road infrastructure" [3], This is the objective and tool of the PIARC Guideline on these human factors spreading the knowledge of human abilities and limitations in traffic which have to be taken into Road Design and Operation. To go into details would fill whole seminar.

According to the EU Directive 2008/96/EC the Infrastructure Safety Management [11], with Road Safety Impact Assessments, Road Safety Audits, Road Safety Inspections, Black Spot Management and Network Safety Management have to be implemented. Romania has done that as one of the first European countries following the recommendations of the EU TA Project [12 $+13]$.

PIARC has developed the specific guidelines for Road Safety Audits (RSA) for the design phase of new projects with detailed checklists for the different design phases and for regular Road Safety Inspections (RSI) of existing roads with a Catalogue on Design Safety Problems and potential Countermeasures.

The bases for the Inspection Guideline have been developed in the Technical Assistance project for Romania in 2004 [12]. In that project it was found out that newly rehabilitated and - misguided by the EU Safe Star recommendations - widened national roads had been developing to axes of 
ROMANIAN JOURNAL

OF TRANSPORT INFRASTRUCTURE

Hans-Joachim Vollpracht

The safe road transport system approach

accidents. The new $12 \mathrm{~m}$ wide 2 lane cross-section with wide hard shoulders of 2,5 m made the traffic faster and dangerous especially within the built up areas along DN 1 with 1 fatality per 2 kilometers and year.

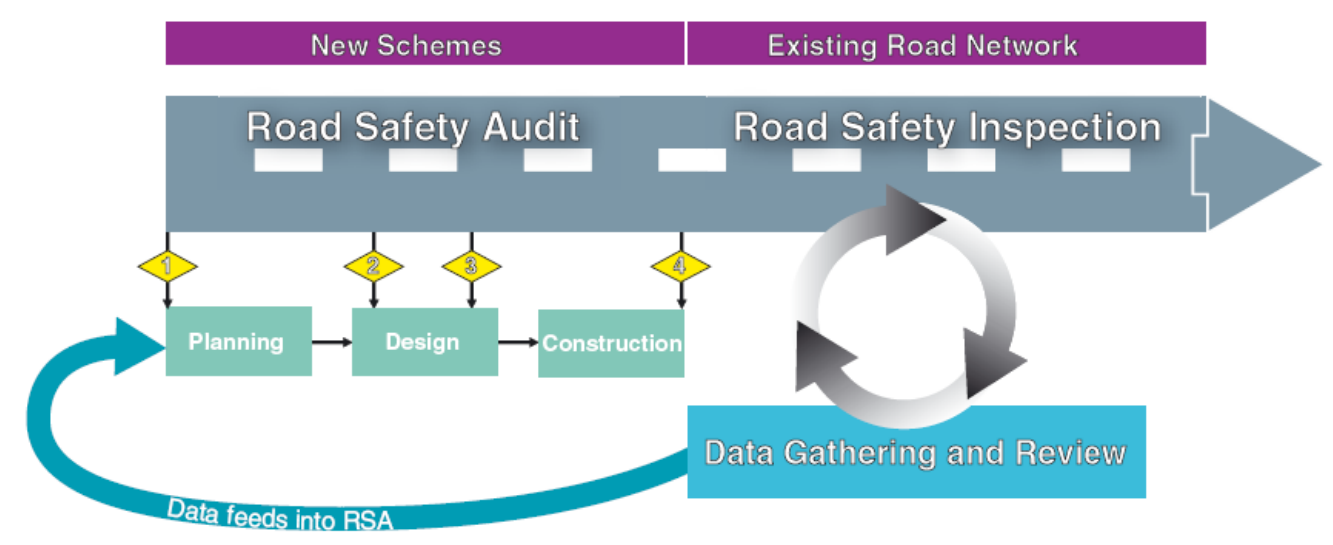

Figure 11. Differentiation between RSA and RSI PIARC Guidelines for Road Safety Audits and Inspections [5].

In 1992 It was found out by the German Highway Research Institute, BASt [14], that this cross-section (b2s) has the highest accident cost rates per 1 million vehicle kilometres per year and it has been exchanged in German design standards by the $2 b+1(b=3,5 \mathrm{~m}$ lane width) [15] .

Accident severity of cross sections,

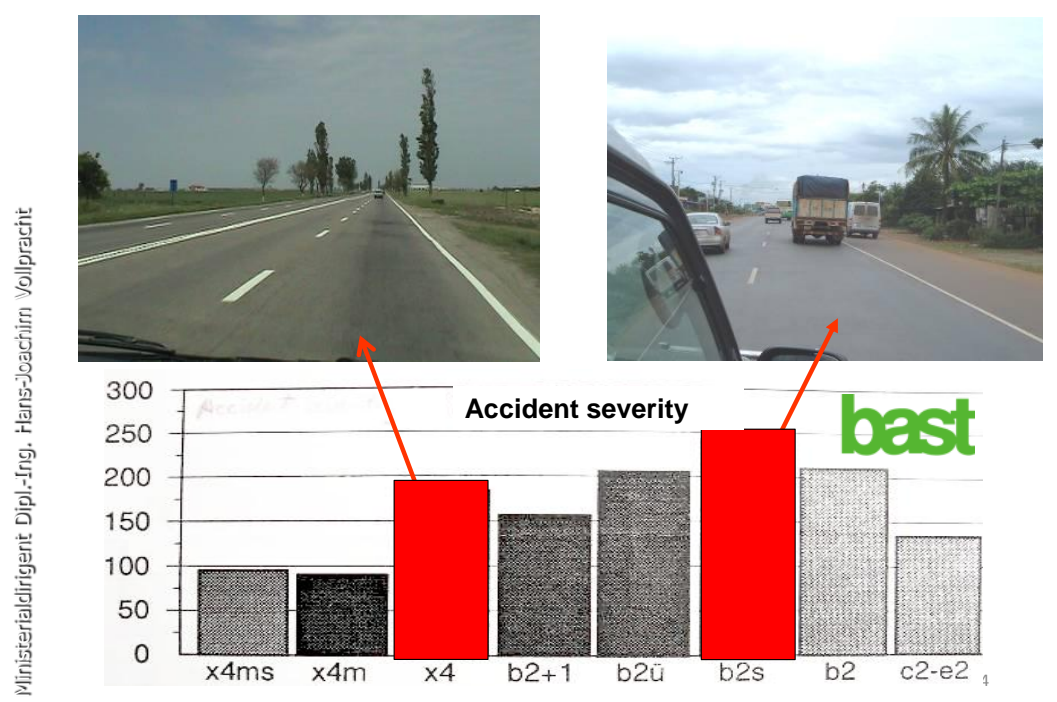

Figure 12. Accident cost rates of different cross sections, Source: BASt plus pictures of the author 
These and other international research publications have been taken to the PIARC Catalogue of Design Safety Problems and potential Countermeasures [16]

\subsection{The problems of fast rehabilitations of roads}

The steep increase of accidents happened in Eastern Germany when the surfaces of the carriageways where rehabilitated just by new asphalt layers seems to be a problem in most emerging countries such as in Bosnia Herzegovina in the last years where the author also found lots of memorials especially along the newly rehabilitated national and provincial roads.

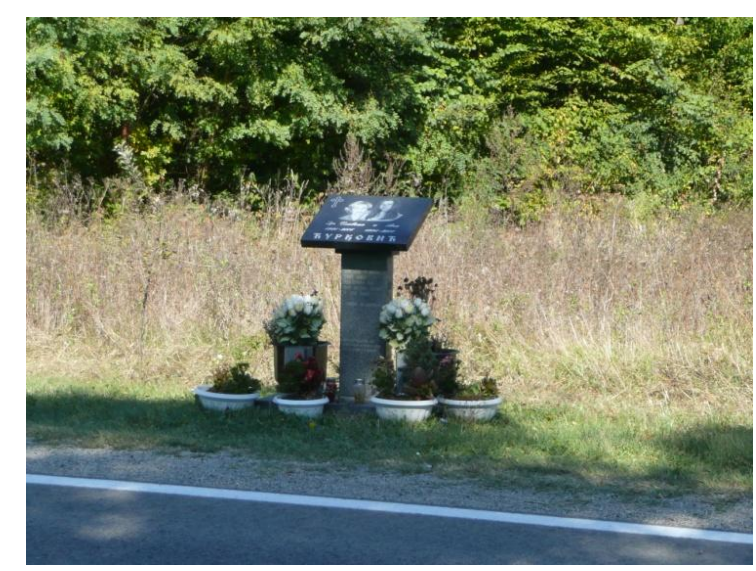

Figure 13. Memorial for road traffic victims in the Republic of SRPSKA Source foto of the author

By a World Bank project [17] it was strongly recommended to perform Road Safety Inspections (RSI) before ordering of the design for the rehabilitation work. Deficiencies in road geometry and for vulnerable road users should be removed as part of the rehabilitation work. The designer should include the recommendations from the RSI Report into his drawings and project documents. These should be audited before the construction and checked again in a pre-traffic opening Road Safety Inspection to ensure that the road is safe, the upper layer sufficiently skid resistant and that the traffic is regulated properly. 


\section{AN EFFICIENT STRATEGY FOR ECONOMICAL DEVELOPMENT} AND ROAD SAFETY, THE EXAMPLE OF THE STATE OF BRANDENBURG (GERMANY)

\subsection{The reactive and proactive road safety measures}

Motivated by the steep increase of memorials along the roads, the government of Brandenburg developed very soon a road safety concept - the first of Eastern Germany. The main pillars of that were similar to those of the UN Global Plan of Action for Road Safety 2011:

- The Government established six regional authorities and two central ones, one for the motorway management and one for cross cutting issues to build up an efficient Road Safety Management, similar to a road Safety Agency as asked for by the UN Global Plan.

- Road Accident Commissions have been implemented

- The fleet of cars was brought up to European standards in a short time.

- A main pillar improving road safety was the implementation of road user campaigns with the focus on speed reduction, avoiding alcohol drinking and show more consideration for other roads user especially vulnerable ones. In Brandenburg we started the campaign "Brandenburg should better drive" with large posters along the motorways and rural roads.

- The steeper decrease of accidents with fatalities of $26.6 \%$ among the decrease of severe accidents by $22 \%$ is the proof of the growing capacity and competence of the emergency services in the early 5 years.

The first network safety management system (NSM), called BASTA, has been implemented in 2002 for the detection the most dangerous road sections with the highest avoidable accident cost density [18] 


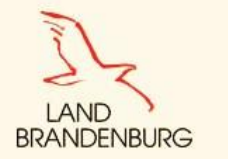

\section{Fatalities (killed people) in Brandenburg}

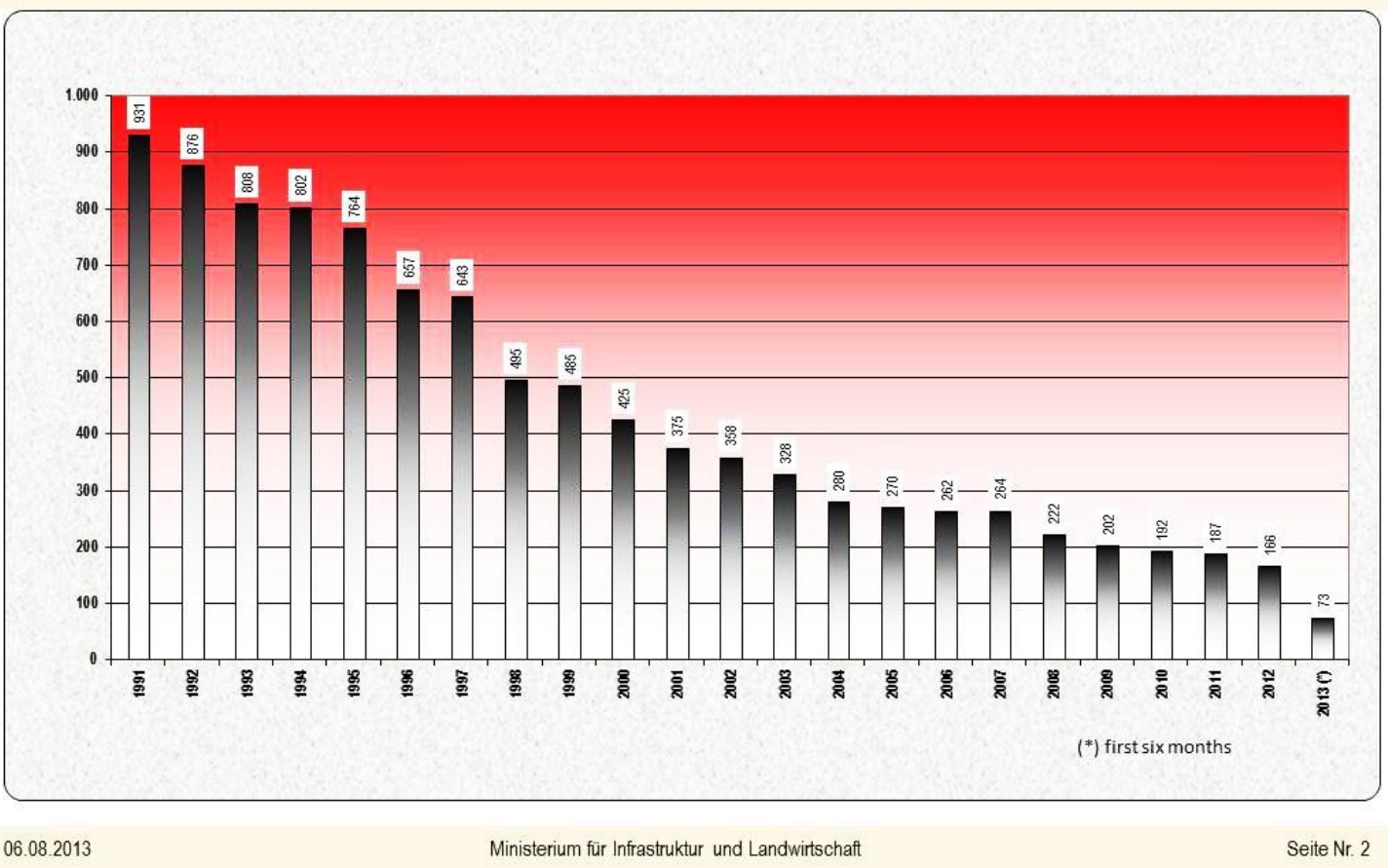

Figure 14. The reduction of fatalities by road accidents in Brandenburg Souce: Ministry of Urban development, housing and Transport 2013

Those measures did decrease the numbers of accidents remarkably but they have not solved the problems of accessibility of the cities in the shadow rooms of the country far away from the Trans European Road Network (TERN) of motorways.

\subsection{The development of an efficient and safe Road Network}

An efficient and safe road network is organized like our blood system: It is a hierarchy of

- Main arteries

- Distributors

- and capillaries to access the single cells in the muscles and organs. 
ROMANIAN JOURNAL

OF TRANSPORT INFRASTRUCTURE

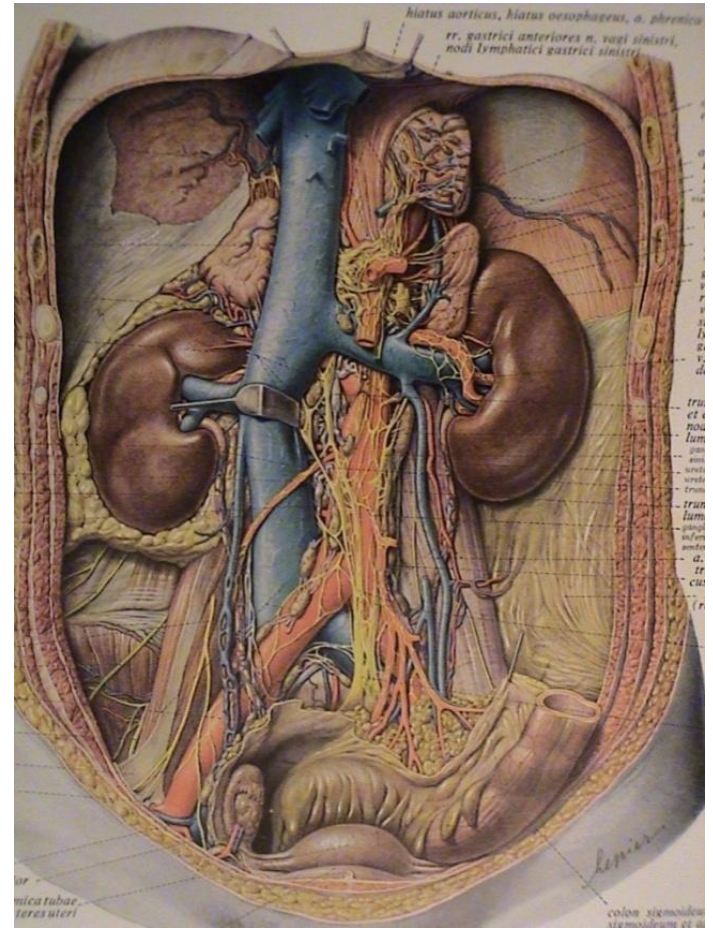

Figure 15. The "bypassing" blood system; Figure 16. The Road system of

Source: Medical lexicon

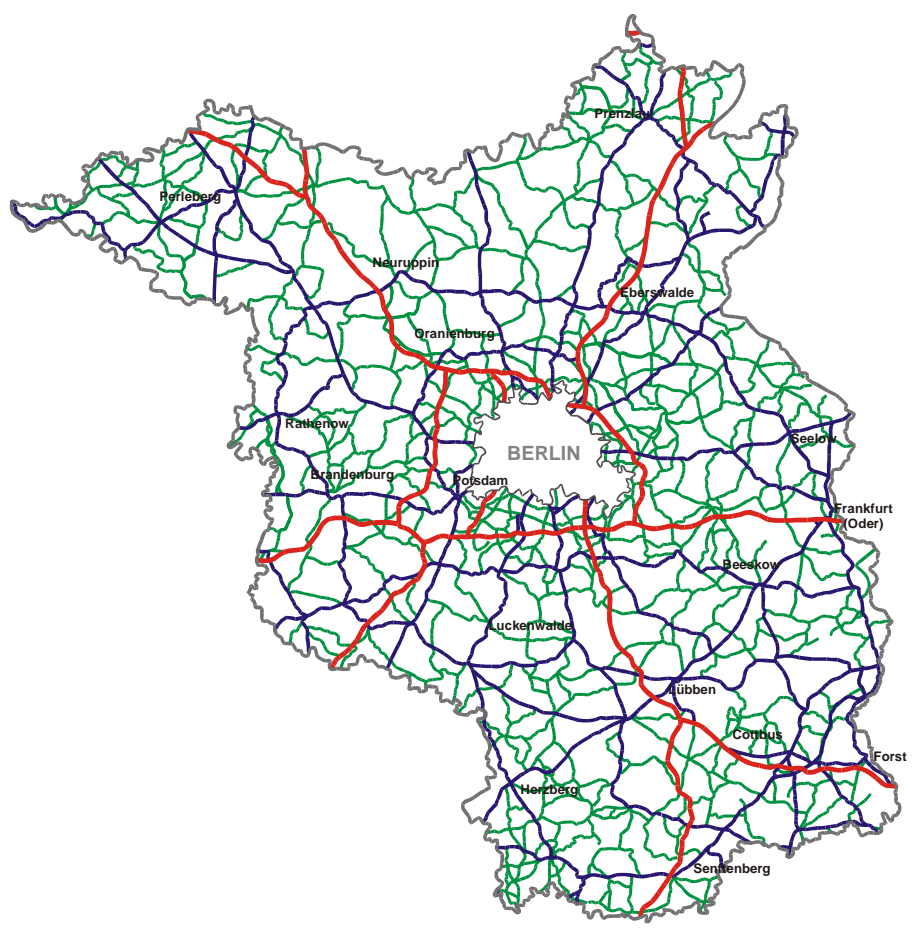

Brandenburg

Source: Ministry of Urban

development, housing and Transport

The blood moves much faster in the Main Arteries:

- main arteries to legs and arm $5.8 \mathrm{~cm} / \mathrm{s}$ than in the Organs

- arterioles $0.28 \mathrm{~cm} / \mathrm{s}$

- capillaries $0,05 \mathrm{~cm} / \mathrm{s}$

So it is with the road network: For our economies the traffic volume and the speed on our main arteries along far distances has to be higher than in our towns and cities. The main blood vessels never provide their surrounding tissue and the organs directly! Linear ssettlements along highways are like heart attacks for human health and the traffic economy as well as we found in Vietnam, Togo, Egypt, Belgium, Romania and Bosnia Herzegovina as well.

Following this model the German Federal Country of Brandenburg developed an Express Road System of the $2+1$ cross-section, bypassing villages and towns for halve the price for Motorways but sufficient for traffic volumes up to 20,000 vehicles/day. Of course all road projects are audited in all planning 
phases according to the German Road Safety Audit Guideline ESAS[19]. This so called "Blue Network" [20] between the red net of motorways and the green net of normal rural roads has stabilized the economic situation of many small towns and villages by faster and safer connections to the Trans European Road Network (TERN) of motorways with an increase of investments in their industry and places of labour. It opened the way for more traffic calming measures in the cities and villages with the remarkable reduction of serious accidents and higher quality of life of their citizens [21].

This strategy was also recommended for Romania as a first step of the Bacau Bypass and later for the Republic of SRPSKA with the option of widening the $2+1$ express roads later to motorways when the limit of 20.000 vehicles/day is expected to be reached.

In the case of the Bacau Bypass [22] the World Bank did commend this proposal:

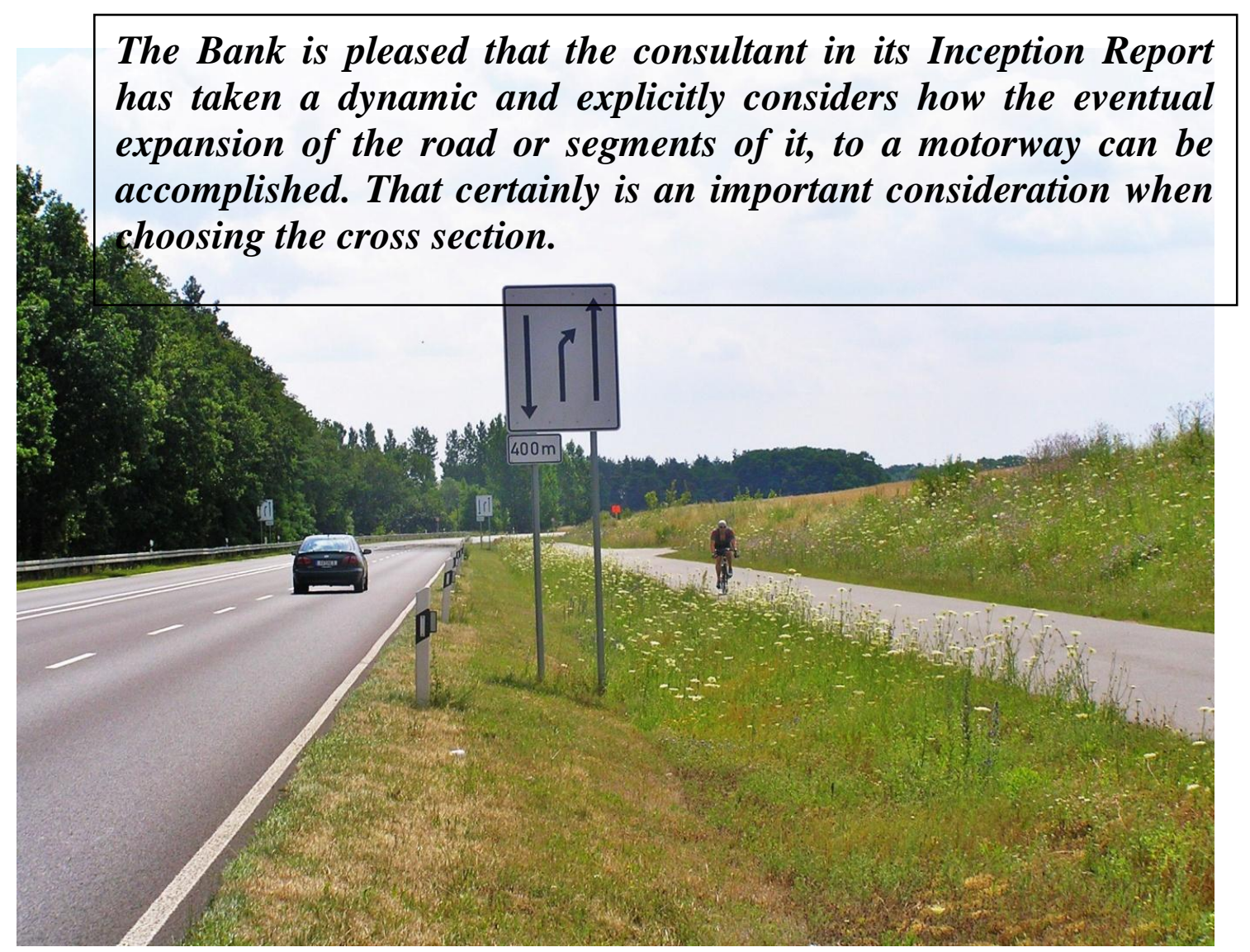

Figure 17. German example of the $2+1$ cross section in Brandenburg Source: Photo of the author 
ROMANIAN JOURNAL

OF TRANSPORT INFRASTRUCTURE

Hans-Joachim Vollpracht

The safe road transport system approach

Develop the motorways stepwise from the $2+1$

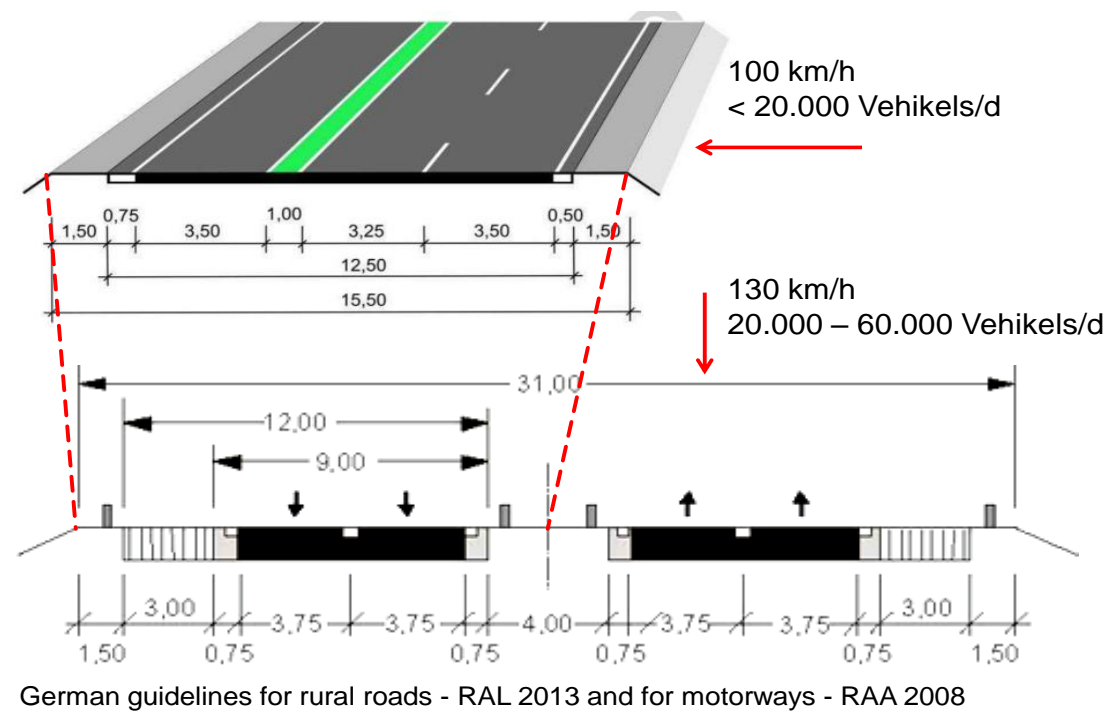

Figure 18. Adapt the motorway system stepwise to the traffic volume, Source German Guidelines

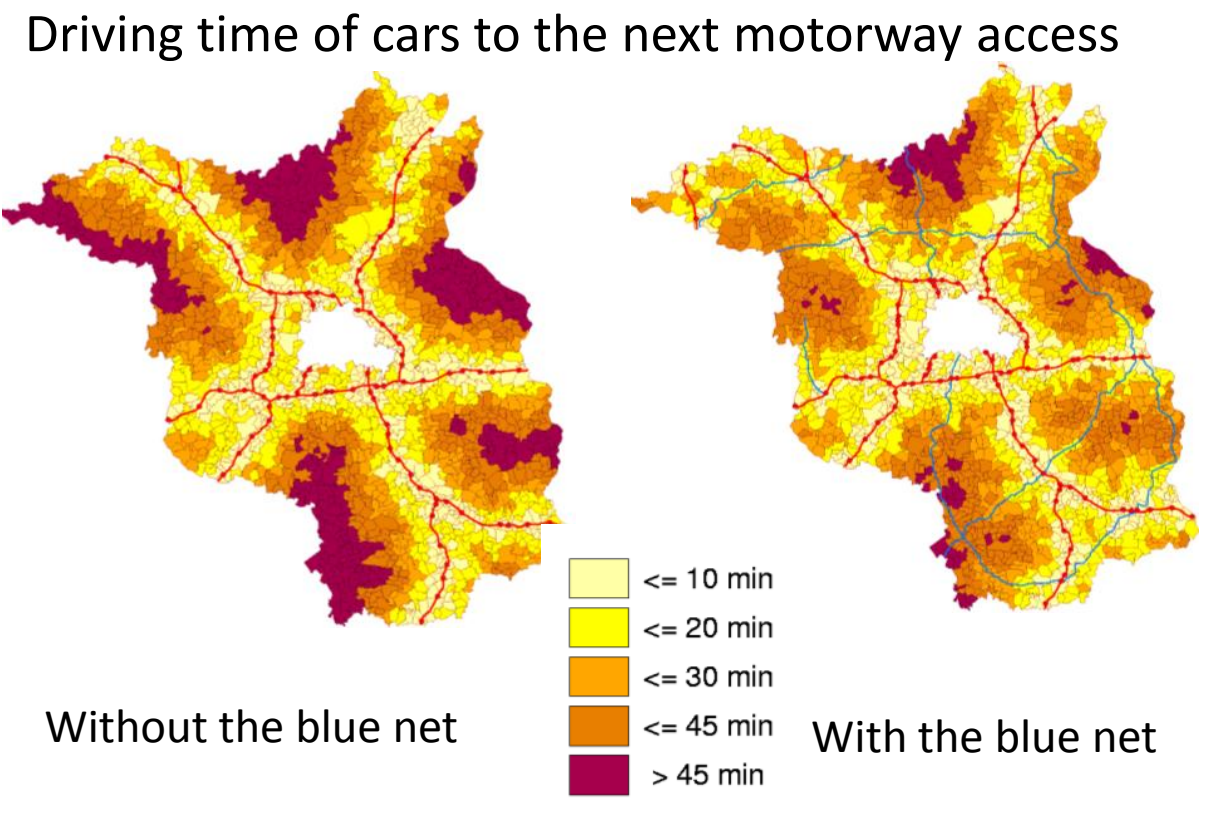

Figure 19. The effect of the blue net on the accessibility to the TERN 


\section{CONCLUSIONS}

The important decrease in road traffic fatalities and severe injuries achieved over the past ten years in several countries which have adopted a holistic approach to road safety more or less in line with the safe system concept, demonstrates that we currently have proven methodological tools to improve significantly road safety

In the area of road design and operations, a number of guidelines which integrate the experience of advanced countries have been produced by the World Road Association and have been applied successfully in various countries. They are made available free of charge to the road community form the Association's web-site.

In countries of emerging economy which experience a fast increase in the rate of motorization and have to up-grade their road network the risk of a large degradation of road safety is high if no national road safety plan is developed and implemented.

The example of the state of Brandenburg shows however that there is no inevitability in this area if correct action is taken. It has been possible to reduce the number of severe accidents with fatalities and injuries remarkably by improvements in all of the 5 pillars of the UN Plan of action. By the modernization of the ambulance system, the fleet of vehicles and the improvement of traffic education in schools and driving schools and by public awareness campaigns good results could be achieved. But above all it was the improvement of the road network with safer Motorways, the blue net of express roads and the traffic calming measures in villages and towns which finally lead to a reduction of $72 \%$ of severe accidents and of $81 \%$ of fatalities within 20 years.

Nevertheless the achieved fatality rate of 6.6 is still $60 \%$ higher than the German average of 4 . This is on one hand related to longer daily drives of the inhabitants to work by car than in densely populated areas of Germany, on the other hand to the lack of forgiving road sides. The tree lined roads are a special road safety problem, unsolved until now because of environmental protections.

On the basics of a detailed modern GPS based Accident Database and Management Romania should follow up the main reasons for accidents by research and development of universities. The recommendations from the earlier EU Technical Assistant Projects may help to create a national Road Safety Action Plan. This work should be coordinated by a national Road Traffic Safety Agency with functions as a secretariat for the National Council of the involved 
Ministries of Interior, Education, Traffic and Health as they were created in the Republic of SRPSKA by the World Bank Project [11].

\section{REFERENCES}

[1] European Transport Safety Council's (ETSC) 8th Road Safety Performance Index Report on Ranking EU Progress on Road Safety; June 2014

[2] World Health Organisation, 3rd State of Road Safety around the World

[3] The UN Global Plan for the Decade of Action for Road Safety 2011 to 2020

[4] „Road Safety Measures Implementation - Safety” Audit System for Romania EuropeAid/114414/D/SV/RO: Road Safety Inspection curricula

[5] PIARC publication in Routes and Roads 347 by the author

[6] European Transport Safety Council: Transport Safety Organization in Public and Private sectors, 2003 (www.etsc.be)

[7] EU Twinning project for enhancing Road Safety in Egypt, EG08/AA/TP13

[8] The PIARC four strategic themes (www.piarc.org)

[9] The PIARC Guidelines on Road Safety (www.piarc.org)

[10] PIARC Human factors guideline (www.piarc.org)

[11] EU Directive 2008/96/EC on Infrastructure Safety Management 2008

[12] „Road Safety measures implementation of Safety” Audit System for Romania, Europe Aid/114414/D/SV/RO

[13] „Technical Assistant for Implementation of Road Safety Measure in Romania”, Europe Aid/121354/D/SV/Ro

[14] „The safety of one carriageway cross sections”, BASt, 1992

[15] German Guideline for Rural Roads (RAL)

[16] PIARC Catalogue on Design Safety Problems and potential Countermeasures 
ROMANIAN JOURNAL

OF TRANSPORT INFRASTRUCTURE

Hans-Joachim Vollpracht

The safe road transport system approach

[17] „Improvement of Road Safety Management and Conditions in the Republic” World Bank Project: SRPSKABA-RISP-4371BA/RS-QCBS-CS-10-14/RSS

[18] „Brandenburgisches Expertensystem für die Analyse und Dokumentation von Unfallstrecken" - BASTA - latest edition 2005

[19] Empfehlungen zur Durchführung des Verkehrssicherheitsaudits ESAS

[20] „Grünes Licht für Blaues Netz“ (Green light for the Blue Net) Ministry of Urban Development, Hausing and Transport, Brandenburg, 2001

[21] „Leitfaden für Ortsdurchfahrten in Brandenburg” (Guideline for Rural Roads crossing built up areas, Ministry für Infrastructure and Landwirtschaft 2011

[22] „Transport Restructuring Project”- IBRD Loan 4757-RO - Consulting Services for Design and Construction Supervision of Bacau Bypass (2007) 